\title{
Od bierzmowania w życiu i posłudze pasterskiej Karola Wojtyly do „bierzmowania dziejów" Jana Pawla II
}

Duch Święty - źródło każdego powołania: osób świeckich, duchownych oraz konsekrowanych: biskupów, kapłanów, sióstr i braci zakonnych. Od Niego biorą początek posługi, charyzmaty i zadania ewangelizacyjne. Działa przez sakramenty, udziela swych darów i natchnień na różne sposoby. Sprawia, że powołanie do świętości jest aktualne i osiągalne dla każdego. Święty Bazyli Wielki podkreślił, że Duch objawia się w sposób szczególny w życiu ludzi świętych. „Święty to miejsce odpowiednie dla Ducha, gdy oddaje siebie do zamieszkania Bogu i nazywa się Jego świątynią"1.

Kanonizacja Jana Pawła II, która odbyła się 27 kwietnia 2014 roku, stanowiła uroczyste potwierdzenie jego świętego życia, które teraz winno jeszcze bardziej inspirować do naśladowania. Pomaga w tym coraz pełniejsza odpowiedź na pytanie o źródła jego świętości czy o drogi jej realizacji. Niewątpliwie sakramenty odgrywają istotną rolę na drodze do świętości. Duch Święty działa w sakramentach, dokonując dzieła uświęcenia. Sakrament bierzmowania szczególnie wiąże się z Duchem Świętym, który uzdalnia chrześcijanina do dojrzałej wiary, składania świadectwa Chrystusowi i świętego życia.

Przedmiotem tego artykułu jest ukazanie znaczenia bierzmowania w życiu młodego Karola Wojtyły, a następnie w jego pasterskiej posłudze jako arcybiskupa krakowskiego. Zrozumienie roli i znaczenia tego sakramentu w życiu indywidualnym i społecznym zaowocowało „bierzmowaniem dziejów”, którego Jan Paweł II dokonał na krakowskich Błoniach, 10 czerwca 1979 roku.

\footnotetext{
${ }^{1}$ Św. Bazyli Wielki, O Duchu Świętym, Warszawa 1999, s. 172.
} 
W bierzmowaniu Duch Święty uczy, że odpowiedzialność za zbawienie własne łączy się z odpowiedzialnością za zbawienie innych, dlatego jest to sakrament apostolstwa. Ponowne „odkrycie obecności Ducha Świętego, który działa w Kościele zarówno na sposób sakramentalny, zwłaszcza poprzez bierzmowanie, jak i za pośrednictwem licznych charyzmatów, zadań i posług"² stanowi jedno z wciąż aktualnych zadań dla wiernych żyjących u początku trzeciego tysiąclecia chrześcijaństwa.

\section{Modlitwa o dary Ducha Świętego}

Karol Józef Wojtyła został ochrzczony w niedzielę 20 czerwca 1920 roku, miesiąc po urodzeniu (18 maja), w kościele parafialnym pw. Ofiarowania Najświętszej Maryi Panny w Wadowicach. Do Pierwszej Komunii św. przystąpił 25 maja 1929 roku. Miesiąc wcześniej zmarła jego matka Emilia Wojtyła, z domu Kaczorowska. Trzy lata później odszedł jego starszy brat, Edmund, na skutek zakażenia chorobą podczas pracy w szpitalu w Bielsku-Białej. Te bolesne doświadczenia jeszcze bardziej związały Karola z ojcem. Karol Wojtyła senior poświęcił wszystkie swe siły wychowaniu syna, przekazaniu mu miłości do Boga i Ojczyzny, szacunku do ludzi, obowiązkowości w nauce i pracy. Karol codziennie rano uczestniczył wraz z ojcem we mszy świętej. Był ministrantem. Od wczesnych lat rozwijał pobożność maryjną przez modlitwę różańcową, nabożeństwo do Matki Boskiej Nieustającej Pomocy, której wizerunek znajduje się w kościele wadowickim, przez nabożeństwo do Szkaplerza w pobliskim klasztorze karmelitańskim i pielgrzymki do sanktuarium Matki Boskiej w Kalwarii Zebrzydowskiej³.

Wpływ religijności ojca na formację duchową syna był bardzo głęboki, o czym świadczą wspomnienia Jana Pawła II: „Patrzyłem z bliska na jego życie, widziałem, jak umiał od siebie wymagać, widziałem, jak klękał do modlitwy"4. Przy innej okazji wyznał: „Nieraz zdarzało mi się budzić w nocy i wtedy zastawałem mojego ojca na kolanach, tak jak na kolanach widywałem go w kościele"5.

Miłość i szacunek do ojca wdowca - pisze George Weigel - były potężnym kompasem, dającym mu [Karolowi] podstawową moralną orientację. [...] Moralna lekcja, jakiej syn nauczył

${ }^{2}$ Jan Paweł II, List apostolski w związku z przygotowaniem Jubileuszu Roku 2000 Tertio millennio adveniente, 45.

${ }^{3}$ Por. tenże, Dar i Tajemnica. W pięćdziesiąta rocznicę moich święceń kapłańskich, Kraków 1996, s. 21-22, 26, 28-29.

${ }^{4}$ A. Frossard, Nie lękajcie się! Rozmowy z Janem Pawłem II, Città del Vaticano 1982, s. 14.

${ }^{5}$ Jan Paweł II, Dar i Tajemnica, dz. cyt., s. 22. 
się od ojca, nie była stoicka, lecz chrześcijańska - była to lekcja cierpienia przemienionego przez wiarę. Życie jego ojca było surowe, jak wspomina później syn, ale surowość dla Karola Wojtyły seniora nie była tylko kwestią skromności narzuconej przez konieczność utrzymania się z małej emerytury. Rodziła się ona z przekonania do chrześcijańskiej ascezy i z niewzruszonej pewności, że prawdziwą miarą człowieka jest jego charakter, a nie bogactwo. Lolek nauczył się także od ojca, że męskość i życie modlitwy nie są sobie przeciwstawné ${ }^{6}$.

Przykład ojca był dla Karola decydujący w jego rozwoju duchowym i wyborze powołania kapłańskiego. „Nigdy nie mówiliśmy z sobą o powołaniu kapłańskim - wyznał po latach Jan Paweł II - ale ten przykład mojego ojca był jakimś pierwszym domowym seminarium"”.

Należy dodać, że ojciec Karol Wojtyła zmarł podczas okupacji, 18 lutego 1941 roku. Dla młodego Karola była to niepowetowana i bardzo dotkliwa strata. Można jednak powiedzieć, że jak życie religijne ojca „po stracie żony i starszego syna niezwykle się pogłębiło"s, tak i Karol, dzięki głębokiej wierze, którą przekazał mu ojciec, znalazł w sobie dość siły, by iść dalej przez życie i dążyć do świętości.

Po ogólnym zarysowaniu historii rodziny i rozwoju wiary u młodego Karola Wojtyła, warto teraz zwrócić uwagę na pewne wydarzenie związane z Osobą Ducha Świętego. Kiedy Karol miał dziesięć lub dwanaście lat, ojciec pokazał mu w książeczce do nabożeństwa modlitwę o dary Ducha Świętego. Podkreślił przy tym, że codzienne jej odmawianie pomoże mu w gorliwym wypełnianiu obowiązków. Była to stosunkowo krótka modlitwa, złożona z ośmiu wersów, zawierająca prośby o siedem darów Ducha Świętego. Każda z próśb wskazywała cel, do którego poszczególne dary prowadzą .

Do tego wydarzenia Jan Paweł II nawiązał w przemówieniu do młodzieży w Warszawie (3 czerwca 1979) i w Hradcu Králové (26 kwietnia 1997), a także w opublikowanych rozmowach z Vittorio Messorim i André Frossardem ${ }^{10}$. Przy

${ }^{6}$ G. Weigel, Świadek nadziei. Biografia papieża Jana Pawła II, Kraków 2000, s. 62.

${ }^{7}$ Jan Paweł II, Dar i Tajemnica, dz. cyt., s. 22; zob. A. Cazzago, ,,Jeszcze dziśs stysze jego głos”. Jan Pawet II mówi o swoim ojcu, „Communio” 30 (2010) nr 2, s. 79-87.

${ }^{8}$ A. Frossard, Nie lękajcie się! Rozmowy z Janem Pawłem II, dz. cyt., s. 14.

${ }^{9}$ „Duchu Święty, proszę Cię / O dar mądrości do lepszego poznawania Ciebie i Twoich doskonałości Bożych, / O dar rozumu do lepszego zrozumienia ducha tajemnic wiary świętej, / O dar umiejętności, abym w życiu kierował się zasadami tejże wiary, / O dar rady, abym we wszystkim u Ciebie szukał rady i u Ciebie ją zawsze znajdował, / O dar męstwa, aby żadna bojaźń ani względy ziemskie nie mogły mnie od Ciebie oderwać, / O dar pobożności, abym zawsze służył Twojemu Majestatowi z synowską miłością, / O dar bojaźni Bożej, abym lękał się grzechu, który Ciebie, o Boże, obraża. Amen".

${ }^{10}$ Por. Jan Paweł II, Przemówienie do młodzieży, Warszawa, 3.06.1979, [w:] Pielgrzymka Jana Pawła II do Polski: przemówienia, dokumentacja. Tekst autoryzowany, Poznań-Warszawa 1979, s. 27-28; tenże, Potrzebuje was Chrystus i Kościót, Hradec Králové, 26.04.1997, „L’Osservatore 
każdej z tych okazji wskazywał na różne owoce, jakie ta „ważna lekcja” przyniosła w jego życiu.

W książce Przekroczyć próg nadziei Jan Paweł II podkreślił, że wtedy po raz pierwszy zrozumiał, co znaczy być prawdziwym czcicielem Boga, co znaczy oddawać Mu cześć w Duchu i Prawdzie (por. J 4, 35). Stopniowo odkrywał znaczenie Chrystusowego odkupienia, znaczenie Kościoła jako wspólnoty zbawienia oraz swoje powołanie w Kościele ${ }^{11}$. Ojciec potrafił otworzyć serce i umysł Karola na Ducha Świętego. Można przypuszczać, że Karol potrafił powiązać ze sobą w pewien sposób głębokie życie duchowe swojego ojca, jego wiarę, postawę odpowiedzialności i męstwa, miłość ojcowską z jego nabożeństwem do Ducha Świętego. Zrozumiał wtedy, że wiara nie polega tylko na zachowaniu przykazań i udziale w celebracjach liturgicznych, lecz także na tym, by otworzyć się na działanie Ducha Świętego.

André Frossard podczas jednej z rozmów z Papieżem, zamieszczonej w książce Portret Jana Pawła II, zapytał o modlitwę: „Jak się Ojciec Święty modli?”. Odpowiadając na to pytanie, Jan Paweł II nawiązał do omawianego wydarzenia ze swojego dzieciństwa. Stwierdził, [była to] „lekcja duchowa, trwalsza i silniejsza niż wszystkie, jakie mogłem wyciągnąć w następstwie lektur czy nauczania, które odebrałem"'12. Powodem tego było przede wszystkim świadectwo wiary jego ojca wyrażone w głębokim przekonaniu o potrzebie modlitwy do Ducha Świętego. „Z jakim przekonaniem on do mnie mówił! Jeszcze dziś słyszę jego głos"'13. Od tamtego dnia przez całe życie Karol Wojtyła pozostał wierny odmawianiu tej modlitwy o dary Ducha Świętego. Najpierw modlił się - jak wspomina - o konkretne dary Ducha Świętego, z czasem zrozumiał, że trzeba Duchowi pozwolić, by On modlił się w nas. Podkreślił również, że wszystkie dary znajdują swoje wypełnienie w miłości ${ }^{14}$.

Podczas spotkania z młodzieżą przy kościele św. Anny w Warszawie, 3 czerwca 1979 roku, Jan Paweł II zwrócił uwagę, że człowieka należy „mierzyć miarą Ducha Świętego", to znaczy jego wrażliwością duchową i moralną oraz otwartością na działanie Boga. Tylko Duch Święty - mówił Papież - może wypełnić człowieka, „doprowadzić go do spełnienia poprzez miłość i mądrość”. W tym kontekście Ojciec Święty podkreślił potrzebę modlitwy o dary Ducha Świętego, nawiązując właśnie do wspomnienia z dzieciństwa:

Romano", wyd. pol., 1997 nr 8-9, s. 13; A. Frossard, Portret Jana Pawła II, Kraków 1990, s. 56; Jan Paweł II, Przekroczyć próg nadziei, Lublin 1994, s. 115.

${ }^{11}$ Por. Jan Paweł II, Przekroczyć próg nadziei, dz. cyt., s. 115.

${ }^{12}$ A. Frossard, Portret Jana Pawła II, dz. cyt., s. 56.

13 Tamże.

${ }^{14}$ Por. tamże, s. 57. 
Tak jak kiedyś mój rodzony ojciec włożył mi w rękę książkę i pokazał w niej modlitwę o dary Ducha Świętego - tak dzisiaj ja, którego również nazywacie „ojcem”, pragnę modlić się z warszawską i polską młodzieżą akademicką: o dar mądrości - o dar rozumu - o dar umiejętności, czyli wiedzy - o dar rady - o dar męstwa - o dar pobożności, czyli poczucia sakralnej wartości życia, godności ludzkiej, świętości ludzkiej duszy i ciała - wreszcie o dar bojaźni Bożej, o którym mówi Psalmista, że jest on początkiem mądrości (por. Ps 111, 10). Przyjmijcie ode mnie tę modlitwę, której nauczył mnie mój ojciec - i pozostańcie jej wierni ${ }^{15}$.

Wezwał młodych, by otwarli się na działanie Ducha: „Odważcie się przyjąć tę miarę, którą pozostawił nam Chrystus w Wieczerniku Zielonych Świąt - a także w wieczerniku naszych dziejów"16.

W homilii do młodzieży w Hradcu Králové Jan Paweł II podkreślił, że Kościół przekazuje Ducha Świętego zwłaszcza przez sakramenty. Modlitwa do Ducha Świętego pomaga odnaleźć właściwą drogę w życiu i pokonać trudności. Powołując się na osobiste doświadczenie, radził młodym:

Módlcie się do Ducha Świętego, aby był obecny w waszym życiu. Mnie samemu doświadczenie działania Ducha Świętego zostało przekazane w sposób szczególny przez mego ojca, kiedy byłem właśnie w waszym wieku. Gdy przeżywałem trudności, polecił mi modlić się do Ducha Świętego, i to polecenie ukazało mi drogę - drogę, którą postępuję do dzisiaj. Mówię wam o tym moim doświadczeniu, bo i wy jesteście młodzi, jak ja byłem wówczas. A mogę mówić na podstawie wielu lat życia, przeżytych także w czasach trudnych ${ }^{17}$.

Nauka o darach Ducha Świętego i w sposób szczególny modlitwa do Niego wychowują do ,nieustannego dialogu z Duchem Świętym oraz do ufnego i pełnego miłości poddania się Jego kierownictwu" ${ }^{18}$. Ukazują istotne elementy dynamiki duchowego życia chrześcijanina: „rozumienie (dary mądrości, wiedzy [umiejętności] i rozumu), podejmowanie decyzji (dary rady i męstwa), wytrwałość i dojrzewanie w osobowej więzi z Bogiem, zarówno przez życie modlitewne, jak i przez przestrzeganie ewangelicznych zasad postępowania (dary pobożności i bojaźni Bożej)"19. Wyzwaniem dla młodości jest wolność człowieka, która „swoje wypełnienie znajduje w miłości”. Duch Święty jest więzią miłości Ojca

${ }^{15}$ Jan Paweł II, Przemówienie do młodzieży, dz. cyt., s. 27-28.

${ }^{16}$ Tamże, s. 28.

${ }^{17}$ Jan Paweł II, Potrzebuje was Chrystus i Kościót, dz. cyt., s. 13.

${ }^{18}$ Tenże, Duch Święty źródtem nowego życia i obfitości darów, [w:] tegoż, Wierzę w Ducha Świętego, red. S. Dziwisz, H. Nowacki, T. Rakoczy, M. B. Bielecka, Città del Vaticano 1992, s. 346-347.

${ }^{19}$ Tamże. 
i Syna. „Ta zaś mieści w sobie wszystkie dary Ducha Świętego, a przede wszystkim bojaźń Bożą, początek wszelkiej mądrości”"20.

Trzeba stwierdzić, że słowa ojca padły na podatny grunt duszy Karola, jego wrażliwości religijnej i skłonności do życia modlitewnego. Były jak ziarna rzucone na dobrą glebę, która wydaje stokrotny owoc. Były to także słowa poparte świadectwem życia Karola Wojtyły seniora. Stanowiły niejako zaproszenie, by poddać się działaniu Ducha, otworzyć dla Niego serce i umysł. Za kilkoma prośbami do Ducha Świętego skrywało się duchowe bogactwo, które Karol Wojtyła odkrywał przez kolejne lata życia.

\section{Dojrzałość w wierze}

Warto zaznaczyć, że młody Karol otrzymał modlitwę o dary Ducha Świętego kilka lat przed bierzmowaniem, co na pewno utorowało mu drogę do jego owocnego przeżycia. Niestety nie ma wielu informacji związanych z przyjęciem przez niego tego sakramentu. Zwrócimy uwagę zwłaszcza na znaczenie imienia, które wybrał bierzmowany Karol Wojtyła.

Do bierzmowania przystąpił kilka dni przed egzaminem maturalnym, 3 maja 1938 roku. Sakramentu udzielił abp Stefan Sapieha, który w tym czasie wizytował parafię w Wadowicach. Świadkiem do bierzmowania był ojciec kolegi gimnazjalnego, Zbigniewa Siłkowskiego ${ }^{21}$. Karol na bierzmowaniu przyją imię św. Huberta.

Wybór patrona, żyjącego na przełomie VII i VIII wieku świętego biskupa Liège, który ewangelizował tereny Brabancji i Ardenów, może nieco zaskakiwać. Jan Paweł II zapytany, dlaczego przyjął właśnie to imię, wskazał, że w tamtym okresie życia pozostawał pod silnym wpływem twórczości Karola Huberta Rostworowskiego, wielkiego dramaturga pierwszej połowy XX stulecia ${ }^{22}$.

Karol Hubert Rostworowski urodził się 3 listopada 1877 roku w Rybnej niedaleko Krakowa. Dorastał w atmosferze nieprzyjaznej religii. Znajdował się pod wpływem oddziaływania prądów ideowych epoki końca wieku XIX, odrzucających dogmatyzm katolickiej wiary. W wieku ponad trzydziestu lat Rostworowski

${ }^{20}$ A. Frossard, Portret Jana Pawła II, dz. cyt., s. 57.

${ }^{21}$ Por. J. Moskwa, Droga Karola Wojtyty, t. 1: Na tron Apostołów 1920-1978, Warszawa 2010, s. 25. Egzamin dojrzałości zdał 14 maja 1938 roku. Zob. Kalendarium życia Karola Wojtyły, oprac. A. Boniecki, Kraków 1983, s. 37. Warto wspomnieć, że Zbigniew Siłkowski poprosił ojca Karola Wojtyły na świadka swojego bierzmowania. Zob. Z. Bieniasz, Kochana stara buda..., Wadowice 1986, s. 58-59.

${ }^{22}$ Jan Paweł II potwierdził to w rozmownie s. Eufrozyną Teresą Rumian, sercanką. Zob. S. Palka, Peotyka dramatu Karola Wojtyly, praca magisterska napisana pod kierunkiem prof. dr. hab. S. Gawlińskiego, Wydział Polonistyki Uniwersytetu Jagiellońskiego, Kraków 2004. 
przeżył głębokie nawrócenie. Zgłosił się do brata Alberta Chmielowskiego, prosząc o przyjęcie do braci tercjarzy, służących ubogim na ulicach Krakowa. Jednak brat Albert nie przyjął go do wspólnoty tercjarzy, doradzając mu, by znalazł własną drogę powołania chrześcijańskiego. Wojtyła nawiązał do faktu tej rozmowy w trzeciej części dramatu Brat naszego Boga. Pierwowzorem postaci młodego człowieka - Huberta, rozmawiającego z bratem Albertem, jest właśnie Rostworowski ${ }^{23}$.

Warto wspomnieć, że w swoich utworach Rostworowski poruszał problemy moralne, poszukując ich rozwiązania w świetle nauki chrześcijańskiej. W życiu osobistym i w działalności społeczno-politycznej pisarz kierował się zasadami wiary i oddaniem sprawom Kościoła i polskiego narodu. Zmarł 4 lutego 1938 roku w Krakowie. Był tak ceniony, że w czasie jego pogrzebu we wszystkich kościołach krakowskich biły dzwony.

Szukając uzasadnienia wyboru imienia dokonanego przez Wojtyłę, trzeba zauważyć, że w tamtym okresie jego życia „,decydujące wydawało się nade wszystko zamiłowanie do literatury, a w szczególności do literatury dramatycznej i do teatru"24. Dlatego postać Rostworowskiego, jego kunszt pisarski oraz świadectwo wiary były dla Wojtyły jasnym wzorem chrześcijańskiej dojrzałości i apostolstwa ${ }^{25}$.

Czas wojny i okupacji niemieckiej wiązał się z wielkimi ofiarami. Wielu rówieśników ze środowiska Karola Wojtyły wybrało walkę o wolność Ojczyzny. Wielu zginęło. Karol widział swoje miejsce w pracy na rzecz zachowania polskiej kultury, przekonany, że jest to także patriotyczne i dalekosiężne zadanie, które Polacy winni podjąć. Mieszkał wówczas na Dębnikach w Krakowie, zaangażował się w Żywy Różaniec prowadzony przez Jana Tyranowskiego, z zawodu krawca, który prowadził głębokie życie duchowe. Po aresztowaniu przez hitlerowców kilku duszpasterzy z parafii św. Stanisława Kostki pojawiła się potrzeba

${ }^{23}$ Por. Brat naszego Boga, [w:] K. Wojtyła - Jan Paweł II, Poezje, dramaty, szkice. Tryptyk rzymski, Kraków 2004, s. 381-386.

${ }^{24}$ Jan Paweł II, Dar i Tajemnica, dz. cyt., s. 9. Ostatnio sztuką wystawioną w Wadowicach w reżyserii Mieczysława Kotlarczyka, w której wziął udział Wojtyła, był dramat Judasz z Kariothu. Por. M. Kolarczyk, K. Wojtyła, O Teatrze Rapsodycznym. 60-lecie powstania Teatru Rapsodycznego, oprac. J. Popiel, Kraków 2001, s. 310. Po przyjęciu do seminarium Karol Wojtyła kontynuował jeszcze próby teatralne, choć jego zaangażowanie nie było już tak znaczące, jak przed podjęciem studiów teologicznych. Warto zwrócić uwagę, że w październiku 1943 roku w podziemnym Teatrze Rapsodycznym rozpoczęło się przygotowanie wystawienia dwóch dramatów Karola Huberta Rostworowskiego: Miłosierdzie i Straszne dzieci. Por. J. Popiel, Karol Wojtyła w świecie teatru, [w:] Przesłanie Jana Pawła II na XXI wiek, red. M. Jacov, F. Ziejka, W. Zuziak, Kraków 2014, s. 132.

${ }^{25}$ Podczas spotkania z twórcami kultury 8 czerwca 1991 roku Jan Paweł II podkreślił, że wiele zawdzięcza osobie i twórczości Rostworowskiego, „wielkiego polskiego pisarza, wielkiego człowieka i wielkiego chrześcijanina", tendencyjnie zapominanego w czasach PRL-u. Wypowiedź ta świadczy o olbrzymim szacunku, jaki Ojciec Święty zachował wobec Rostworowskiego. Por. Jan Paweł II, Bogu dziękujcie, Ducha nie gaście, Città del Vaticano 1991, s. 249. 
objęcia opieką grupy młodzieży. Pod okiem Jana Tyranowskiego odbywała się duchowa, ascetyczna i apostolska formacja młodzieży. Karol był odpowiedzialny za grupkę chłopców, co należy uznać za przejaw jego chrześcijańskiej dojrzałości, odwagi i apostolskiej odpowiedzialności ${ }^{26}$.

\section{Szafarz daru Ducha Świętego}

Przed omówieniem zagadnienia posługi szafarza bierzmowania warto zwrócić uwagę na pneumatologiczny wymiar sakramentu kapłaństwa. Karol Wojtyła miał głęboką świadomość, że kapłaństwo i konsekracja biskupia wiążą się ściśle ze szczególnym darem Ducha Świętego.

Sakrament święceń kapłańskich przyjął 1 listopada 1946 roku w prywatnej kaplicy arcybiskupów krakowskich, z rąk kard. Stefana Sapiehy. Wspominając dzień swoich święceń, Jan Paweł II podkreślił, że gest leżenia krzyżem, podczas śpiewu Veni Creator Spiritus oraz Litanii do wszystkich świętych, oznacza „uniżenie wobec majestatu Boga samego, a równocześnie całkowitą otwartość, ażeby Duch Święty mógł zstąpić, bo przecież On sam jest sprawcą konsekracji”27. Dodał, że kapłaństwo stanowi „szczególne wylanie Ducha Pocieszyciela”28. Posiada ono „tajemniczą moc uświęcającą, jest źródłem i korzeniem powierzonej szczególnej misji ewangelizacji i uświęcenia"29. Kapłan sprawuje sakramenty nie własną mocą, lecz mocą Ducha Świętego ${ }^{30}$.

Konsekracja biskupia oznacza pełnię kapłaństwa Chrystusowego. Karol Wojtyła przyjął święcenia biskupie 28 września 1958 roku w katedrze na Wawelu. Głównym konsekratorem był abp Eugeniusz Baziak. W książce Wstańcie, chodź$m y$ ! - wspominając święcenia biskupie - Jan Paweł II podkreślił aspekt pneumatologiczny konsekracji:

Przy udzielaniu sakramentu święceń kapłańskich namaszcza się ręce, przy biskupich zaś głowę. Jest to również gest mówiący o przekazaniu Ducha Świętego, który od wewnątrz przenika,

${ }^{26}$ Por. M. Szafarski, Perta ewangeliczna. Stuga Boży Jan Leopold Tyranowski 1901-1947, Wrocław 2000, s. 43-45; K. Wojtyła, Apostoł, [w:] tegoż, „Aby Chrystus się nami postugiwat”, Kraków 1979, s. 16-27; M. Maliński, W szkole Jana Tyranowskiego, [w:] Pięknie jest stużyć. Dziedzictwo duchowe Jana Pawła II, red. A. Dobrzyński, Rzym 2013, s. 12-23.

${ }^{27}$ Jan Paweł II, Dar i Tajemnica, dz. cyt., s. 43-44.

${ }^{28}$ Tenże, List do kapłanów na Wielki Czwartek 1998 roku (wstęp).

${ }^{29}$ Tamże.

${ }^{30}$ Por. Jan Paweł II, Dar i Tajemnica, dz. cyt., s. 44; tenże, List do kapłanów na Wielki Czwartek 1998 roku, 2. 
bierze w posiadanie i czyni swoim narzędziem człowieka namaszczonego. To namaszczenie głowy oznacza powołanie do nowych zadań: biskup podejmuje w Kościele zadanie kierowania, a ono go pochłonie dogłębnie. Również to namaszczenie Duchem Świętym ma to samo źródło: Jezus Chrystus - Mesjasz ${ }^{31}$.

Po przyjęciu sakry biskupiej jedną z posług Karola Wojtyły - jak każdego z biskupów - było udzielanie młodzieży sakramentu bierzmowania. Umocnienie Duchem Świętym jest jednym z najważniejszych pasterskich zadań: „Biskup, sprawujący swoją posługę, ma tak wiele okazji, by sprawować ten sakrament, znacząc olejem świętego Krzyżma różne osoby i przekazując im dar Ducha Świętego, który jest źródłem życia w Chrystusie" 32 .

Pierwsza wzmianka w Kalendarium życia Karola Wojtyly o sprawowaniu tego sakramentu: „,bierzmowanie dzieci głuchoniemych w kaplicy na Pędzichowie” (w Krakowie) została opatrzona datą 9 listopada 1958 roku. Ostatni raz kard. Wojtyła udzielił bierzmowania 30 września 1978 roku w parafii Opatrzności Bożej na osiedlu „Złote Łany” w Bielsku-Białej ${ }^{33}$. Pierwszy ślad pisemny, na który należy zwrócić uwagę, stanowi wiersz Narodziny wyznawców pochodzący z roku 1961. Związany jest z udzieleniem bierzmowania „w pewnej podgórskiej wsi”. W maju tegoż roku bp Wojtyła odbył wizytację dekanatu zakopiańskiego. Był w trzynastu parafiach. Być może przemyślenia i odczucia, które zrodziły się podczas sprawowania tego sakramentu, stały się inspiracją do napisania wiersza, który składa się z dwóch części. W pierwszej przedstawione są „myśli biskupa udzielającego sakramentu bierzmowania”, w drugiej natomiast „myśli człowieka przyjmującego sakrament bierzmowania" ${ }^{34}$. Warto pokrótce przyjrzeć się bliżej zawartym w tym wierszu przemyśleniom.

W sakramencie bierzmowania szafarz jakby uwalnia ukryte energie, od których ,człowiek winien wezbrać” duchowo, dojrzeć w postawie ufności, w swych myślach przechodzących w wybór, następnie w „głębię czynów” i w „wolę walki”. Biskup dostrzega działanie Ducha Świętego w oczach młodego człowieka, które są „zwierciadłem myśli” wyrażających jakby „ciśnienie spraw niewidzialnych uwięzionych w pękach atmosfer”. W sakramencie bierzmowania „,człowiek spotyka Tego, który go stale wyprzedza: miejscem spotkania jest męstwo, i każdy z nas jest twierdzą" 35 .

\footnotetext{
${ }^{31}$ Tenże, Wstańcie, chodźmy!, Kraków 2004, s. 32.

${ }^{32}$ Tamże, s. 34-35.

${ }^{33}$ Por. Kalendarium życia Karola Wojtyty, dz. cyt., s. 163 i 833.

${ }^{34}$ K. Wojtyła - Jan Paweł II, Poezje, dramaty, szkice. Tryptyk rzymski, Kraków 2004, s. 128-132.

${ }^{35}$ Tamże, s. $128-130$.
} 
W przyjmującym bierzmowanie najpierw „kształtuje się myśl”, pytanie o źródło, by mogła „wybuchnąć” prawda o człowieku, która nadaje sens codziennemu życiu i jego przemijaniu. Bierzmowanie wiąże się z otwarciem na działanie Ducha prawdy w różnych sytuacjach życia i na kolejnych jego etapach. „Zbiorę Ciebie ze wszystkich łożysk, z potoków, źródeł światła, z korzeni drzew i słońca płaszczyzn" "36. Owocem współpracy z Duchem jest nasiąknięcie prawdą Chrystusa, osiągnięcie głębi życia i przejrzystości chrześcijańskiego świadectwa ${ }^{37}$.

Należy podkreślić, że Wojtyła skupia uwagę na duchowym wymiarze sakramentu, by wskazać jego nadprzyrodzone znaczenie. Przemyślenia zawarte w tym wierszu wypływają z głębi tajemnicy obecności Boga i z głębi ludzkiej duszy. Zastosowanie formy dwóch podmiotów lirycznych umożliwiło przedstawienie sakramentu z dwóch perspektyw. Wielkości udzielanego daru Ducha winna odpowiadać świadomość i dobra wola tego, kto go przyjmuje. Różne mogą być punkty spotkania, różne bowiem są poziomy przeżywania wiary i dostępowania łaski. Autor ukazał ten sakrament - można powiedzieć - w formie idealnej, ujmując $\mathrm{w}$ wierszu głębokie przemyślenia i nadzieje młodych ludzi, którzy przystępują do bierzmowania.

Język kazań głoszonych przez Karola Wojtyłę był odmienny, musiał być dostosowany do wszystkich wiernych, by obudzić ciekawość umysłów, rozpalić serca pragnieniem łaski i umocnić wolę wyznawania wiary, która winna być przekuwana na codzienne zmagania o godność i świętość chrześcijanina. Świadectwem jego posługi szafarza bierzmowania są kazania wygłoszone przy udzielaniu tego sakramentu. Zachowały się w sumie dwadzieścia cztery kazania, wygłoszone w latach 1965-1978 38 .

Arcybiskup zwracał w nich uwagę m.in. na to, że w bierzmowaniu Duch Święty w sposób szczególny zamieszkuje w duszy ludzkiej i kształtuje ją od wewnątrz. Przeżycie bierzmowania jako osobistej „Pięćdziesiątnicy” ugruntowuje i pomnaża łaskę uświęcającą otrzymaną na chrzcie. Budować w sobie świątynię Ducha oznacza to, by stale zachowywać odniesienie do Boga i by wiara stanowiła duchową siłę do życia i miłości. Duch umacnia chrześcijanina w walce ze złem, z grzechem i słabościami. On także kształtuje i oświeca sumienie. Tym samym uzdalnia do walki z sobą samym, do świadectwa Chrystusowi i wyznawania wiary także przez znoszenie upokorzeń, zniewag i cierpień. Dojrzałość chrześcijanina winna kształtować się najpierw przez modlitwę i udział w sakramentach,

${ }^{36}$ Tamże, s. 132.

${ }^{37}$ Por. tamże, s. $130-132$.

${ }^{38}$ Kazania abp. K. Wojtyły - Jana Pawła II związane z bierzmowaniem wraz z wybranymi katechezami oraz rozważaniami o darach Ducha Świętego zostały opublikowane w zbiorze Narodziny wyznawców. Refleksje o bierzmowaniu, oprac. A. Dobrzyński, Rzym 2014. 
następnie ma się wyrazić w odpowiedzialności za Kościół. Sakrament bierzmowania służy budowaniu żywego Kościoła na drodze zaangażowania apostolskiego. Duch włącza bierzmowanych w uczestnictwo w misji Chrystusa: Kapłana, Króla i Proroka, którą kontynuuje i realizuje Kościół ${ }^{39}$. Arcybiskup podkreślał również prawdę, że łaska Boża uszlachetnia ludzką naturę. W parafii w Jawiszowicach, 20 września 1973 roku, powiedział: „Pamiętajcie, że dzisiaj wraz z sakramentem bierzmowania przyjmujecie także cały program chrześcijańskiego życia"40. Tłumaczył dalej, że „przyjmując ten program, równocześnie przyjmujemy pełną miarę człowieczeństwa, stajemy się pełnowartościowymi ludźmi”41.

Oprócz przybliżenia wiernym podstawowej nauki Kościoła o bierzmowaniu, abp Wojtyła często tłumaczył znaczenie poszczególnych znaków liturgii sakramentu i wypowiadanych słów. Zwracał uwagę na wymiar wspólnotowy celebracji bierzmowania. W liturgii tego sakramentu wyraża się bowiem życie parafii przeżywającej wciąż trwającą Pięćdziesiątnicę. Mówił także o roli świadków bierzmowania, podkreślając, że cała wspólnota winna stanowić międzypokoleniowe ,przymierze świadków”42.

W kazaniach abp. Wojtyły znajduje się wiele nawiązań do aktualnej sytuacji Kościoła, do zagrożeń wynikających $\mathrm{z}$ ateizacji i forsowania ideologii materializmu przez władze komunistyczne PRL. Bierzmując w parafiach, które starały się o budowę świątyń, metropolita wskazywał na potrzebę odważnego świadectwa, mówił także o prawie ludzi wierzących do publicznego wyznawania wiary. W omawianych kazaniach znajduje się wiele ciekawych myśli, nad którymi warto się zastanowić lub wręcz wykorzystać w przygotowaniu młodzieży do bierzmowania. Godne uwagi pozostaje stwierdzenie, że konieczne jest dojrzewanie w chrześcijańskiej wierze, by móc w stosunku do Boga zachować postawę i ufność dziecka. W kazaniu w Nowym Targu, 8 czerwca 1969 roku, abp Wojtyła powiedział:

Człowiek bierzmowany to jest chrześcijanin dojrzały. On w głębi duszy zachowuje nadal charakter i postawę dziecka: dziecka Bożego. Bo dzieckiem Bożym nie przestaje człowiek być nigdy: im dojrzalszy, tym bardziej jest dzieckiem Bożym. Im dojrzalszy w wierze, tym bardziej jest dzieckiem Bożym. Ale zachowując w głębi duszy ten skarb dziecięctwa Bożego, przez bierzmowanie człowiek staje się dojrzałym chrześcijaninem. Dojrzałym w znaczeniu społecznym, staje się bowiem wyznawcą Chrystusa ${ }^{43}$.

${ }^{39}$ Zob. omówienie teologiczne: A. Dobrzyński, Promieniowanie Pięćdziesiatnicy. Karol Wojtyła - Jan Pawet II o bierzmowaniu, [w:] Narodziny wyznawców, dz. cyt., s. 13-34.

${ }^{40}$ Tamże, s. 126.

${ }^{41}$ Tamże.

${ }^{42}$ Tamże, s. 101-102 i 164-166.

${ }^{43}$ Tamże, s. 48. 
Karol Wojtyła w dużej mierze pojmował swoją posługę biskupią jako umacnianie Duchem Świętym i wtajemniczanie w chrześcijaństwo i życie Kościoła. Głoszone słowo Boże przy okazji bierzmowania służyło mu do tego, by dar Ducha Świętego zawarty w sakramentalnym znaku był przyjęty $\mathrm{z}$ otwartym sercem i mógł owocować w przyszłości. Duch, Dawca Darów, hojnie rozlewa swoją łaskę, wzbudza powołania oraz posługi dla dobra i wzrostu Kościoła, Mistycznego Ciała Chrystusa. Biskup, który jest szczególnym narzędziem Ducha Świętego, jest odpowiedzialny za to, by żadne powołanie w Kościele się nie zmarnowało.

\section{Apostolskie aspekty bierzmowania}

Arcybiskup Karol Wojtyła pełnił funkcję przewodniczącego Komisji Apostolstwa Świeckich w latach 1966-1978 jako spiritus movens wielu inicjatyw ${ }^{44}$. Jednym z tematów zaproponowanych Komisji przez kard. Wojtyłę było zagadnienie apostolskich aspektów bierzmowania. Chodziło o odpowiedź na pytanie, jak wykorzystać ten sakrament dla ożywienia apostolstwa świeckich. Postanowiono przygotować krótką instrukcję, biorąc pod uwagę teologiczny i pastoralny wymiar bierzmowania ${ }^{45}$. Warto w tym miejscu przybliżyć tę szerzej nieznaną inicjatywę duszpasterską, której przewodził metropolita krakowski.

Podczas Konferencji Episkopatu we wrześniu 1969 roku przekazano biskupom opracowanie: Uwagi dotyczace bierzmowania jako sakramentu inicjującego świadoma postawe apostolska wiernych. Przygotowane obserwacje były przede wszystkim zaadresowane do Komisji Liturgicznej i Komisji Katechetycznej działających w ramach Konferencji Episkopatu ${ }^{46}$.

W opracowaniu podkreślono bogate podstawy biblijne sakramentu bierzmowania, które upoważniają do przedstawienia konkretnych postulatów. Komisja wskazała na potrzebę szerszego wykorzystania w liturgii bierzmowania tekstów

${ }^{44}$ Warto w tym miejscu wspomnieć, że Komisja została powołana do istnienia 3 sierpnia 1966 roku i działa w ramach Konferencji Episkopatu Polski. W jej skład wchodzą świeccy i duchowni. Cel działania Komisji polega na rozwoju i koordynacji apostolstwa świeckich w Polsce, na trosce o pełne urzeczywistnienie ich powołania w Kościele oraz na realizacji uchwał Soboru Watykańskiego II i wytycznych Stolicy Apostolskiej. Jako organ opiniodawczy oraz informacyjny podejmuje studia nad problematyką apostolstwa świeckich, uchwala wytyczne, tworzy programy, które wchodzą w życie po zatwierdzeniu przez Konferencję Episkopatu Polski. Por. J. Dyduch, Kardynat Karol Wojtyła w stużbie Konferencji Episkopatu Polski, Kraków 2007, s. 41 i 45-46.

${ }^{45}$ Por. tamże, s. 68.

${ }^{46}$ Komisja Apostolstwa Świeckich, Uwagi dotyczace bierzmowania jako sakramentu inicjujacego świadoma postawę apostolska wiernych (cztery strony maszynopisu), Archiwum Kurii Metropolitalnej w Krakowie (AKKW F V - 7/33). 
z Nowego Testamentu, by ukazać „sakrament Ducha Świętego w centrum działalności apostolskiej Kościoła”. Duch Święty sprawia, że prawda Chrystusa jest „prawdą na dziś”, a wcielenie jej w życie niejednokrotnie staje się znakiem sprzeciwu wobec świata.

Liturgia bierzmowania winna zostać poprzedzona „admonicją" skierowaną do kandydatów, przypominając im o „nadprzyrodzonej rzeczywistości sakramentu". Stosowne byłoby także - według propozycji Komisji - wprowadzenie pewnej formy scrutinium, by bierzmowani wyrazili swoją intencję, dobrą wolę i wewnętrzną gotowość do przyjęcia bierzmowania. Proponowano również zmianę modlitw po rycie namaszczenia i przed błogosławieństwem końcowym, by jasno wyrazić dokonane wzbogacenie darami Ducha Świętego i zobowiązanie młodych do apostolstwa.

Komisja zwróciła uwagę na konieczność przepracowania języka katechezy przygotowującej do bierzmowania, by zastosować terminologię dotyczącą chrześcijańskiego świadectwa (świadectwo prawdzie sumienia, świadectwo słowem i czynem) oraz terminologię apostolstwa. Wskazano, że najbardziej optymalnym czasem dla przyjęcia bierzmowania jest osiągnięcie piętnastu lat. W związku z tym postulowano, by nie wiązać bierzmowania z wizytacją kanoniczną parafii i udzielać tego sakramentu przynajmniej co dwa lata, zasadniczo w małych grupach i przed ołtarzem, by nie obniżać godności bierzmowania.

Po opracowaniu i przedstawieniu omówionych powyżej uwag Komisja Apostolstwa Świeckich dalej kontynuowała refleksję dotyczącą bierzmowania. 13 stycznia 1974 roku w Krakowie zorganizowano specjalne zebranie z udziałem zaproszonych gości z różnych diecezji polskich na temat „Apostolskie aspekty bierzmowania w życiu dorosłych katolików świeckich”. Pomogło ono w lepszej i bardziej obiektywnej orientacji i poznaniu doświadczeń duszpasterskich. U schyłku roku 1974 Komisja opracowała dokument Bierzmowanie jako sakrament apostolstwa, który kard. Wojtyła przesłał 12 grudnia 1974 roku do Komisji Duszpasterstwa Ogólnego Episkopatu Polski z prośbą o uwzględnienie wymiaru apostolskiego w przygotowywanej przez tę Komisję instrukcji o bierzmowaniu, uwzględniającej reformę liturgii tego sakramentu wprowadzoną przez Pawła VI w konstytucji apostolskiej Divinae consortium naturae z 15 sierpnia 1971 roku. Podczas zebrania Konferencji Episkopatu Polski 16 stycznia 1975 roku ogłoszono Instrukcję duszpasterska dotycząca sakramentu bierzmowania wraz z załącznikiem Komisji Apostolstwa Świeckich Bierzmowanie jako sakrament apostolstwa ${ }^{47}$.

${ }^{47}$ Por. J. Dyduch, Kardynat Karol Wojtyła w stużbie Konferencji Episkopatu Polski, dz. cyt., s. 68-69; Konferencja Episkopatu Polski, Instrukcja duszpasterska dotyczaca sakramentu bierzmowania, „Notificationes e Curia Metropolitana Cracoviensi” 1975 nr 3-4, s. 30-35; Komisja Apostolstwa Świeckich, Bierzmowanie jako sakrament apostolstwa, „Notificationes e Curia Metropolitana 
Dokument Komisji kierowanej przez kard. Wojtyłę składał się z trzech części: 1) Katecheza bierzmowania, 2) Praktyczne przygotowanie do apostolstwa, 3) Anamneza bierzmowania. W części pierwszej wskazano na związek chrztu i bierzmowania, które należy również ujmować jako sakramenty powołania chrześcijańskiego i apostolskiego. Umocnienie Duchem Świętym w bierzmowaniu ma służyć temu, by każde powołanie chrześcijańskie rozwijało się jako powołanie apostolskie i wyrażało się poprzez integralne świadectwo osoby i życia. W części drugiej zwrócono uwagę, że przygotowanie do bierzmowania stwarza dobrą okazję do wdrożenia młodzieży w apostolstwo przez uczenie jej współpracy i angażowanie młodych w duszpasterstwo parafialne oraz kształtowanie umiejętności spojrzenia na życie oczyma wiary. Trzecia część dokumentu stanowiła podkreślenie prawdy, że „sakrament otrzymany jeden raz domaga się rozbudzenia otrzymanych darów łaski” w kolejnych etapach życia. W związku z tym polecano stworzyć liturgiczno-duszpasterską praktykę ożywiania przyjętej łaski oraz przypomninania o zobowiązaniach wynikających z sakramentu. Komisja wskazała trzy istotne momenty, w których takie przypomnienie należy przeprowadzić: 1) Udzielenie bierzmowania w parafii - przygotowanie winno obejmować także całą wspólnotę, zwłaszcza rodziny i świadków bierzmowania. Przez kazanie czy katechezę lub specjalne słowo adresowane do parafian należy przypomnieć, czym jest bierzmowanie i podjąć tym samym „,rachunek sumienia z apostolstwa”; 2) Zmiana środowiska życia - „stanowi naturalny moment życia domagający się ożywienia łaski bierzmowania”. Przy tych okazjach trzeba uwrażliwiać młodych, że wszędzie są posłani ze świadectwem ewangelicznym; 3) Zawarcie małżeństwa - to również dobra sposobność do przypomnienia o łasce bierzmowania. Małżeństwo i rodzina stanowią pole do apostolstwa, najpierw przez świadectwo ofiarnej miłości i wiary w obrębie małżeństwa, a następnie w środowisku, w którym żyją małżonkowie i rodzina ${ }^{48}$.

Uzasadnione wydaje się stwierdzenie, że przedstawione przez Komisję Apostolstwa Świeckich wskazania znajdują w znacznej mierze swoje odzwierciedlenie w dokumencie Duszpasterskiego Synodu Archidiecezji Krakowskiej (1972-1979) Chrzest i bierzmowanie jako sakramenty wprowadzające w świętość chrześcijańską. Warto przypomnieć, że kard. Wojtyła był także pomysłodawcą

Cracoviensi" 1975 nr 3-4, s. 35-38; Bierzmowanie jako sakrament apostolstwa (cztery strony maszynopisu), Archiwum Kurii Metropolitalnej w Krakowie (AKKW F V - 4/137e).

${ }^{48}$ Instrukcja duszpasterska dotyczaca sakramentu bierzmowania została także opublikowana w: Dokumenty duszpastersko-liturgiczne Episkopatu Polski (1966-1998), oprac. C. Krakowiak, L. Adamowicz, Lublin 1999, s. 31-36. W publikacji nie zamieszczono załącznika Komisji Apostolstwa Świeckich. 
i głównym przewodnikiem prac synodu ${ }^{49}$. Dokument ten, oprócz przypomnienia doktryny bierzmowania, mówi o blaskach i cieniach związanych z duszpasterstwem. Zaleca m.in. przeprowadzenie katechezy w parafii dla rodziców młodzieży bierzmowanej i świadków. Wskazuje, że dzień udzielania tego sakramentu powinien się stać dla całej parafii okazją „odnowienia przymierza z Duchem Świętym", że warto organizować dziękczynienie za dary Ducha Świętego oraz nabożeństwo w pierwszą rocznicę przyjęcia bierzmowania. Poleca także, by młodzież bierzmowana przybywała wraz z duszpasterzami w pielgrzymce do katedry w uroczystość Chrystusa Króla ${ }^{50}$.

Wymienione inicjatywy harmonizowały z nauką Soboru Watykańskiego II, który podkreślił, że chrzest i bierzmowanie uzdalniają wiernych do apostolstwa i do wykorzystania darów duchowych w budowaniu wspólnoty Kościoła ${ }^{51}$. Wzrost aktywnej roli świeckich w Kościele i owocność ich misji w świecie wymaga także pogłębionej świadomości działania Ducha Świętego, a zatem także pogłębionego rozumienia bierzmowania dla realizacji chrześcijańskiego powołania i odpowiedzialności apostolskiej.

\section{Bierzmowanie dziejów}

Czas zmagania się w Polsce $\mathrm{z}$ reżimem komunistycznym zwalczającym chrześcijańską wiarę wymagał od Kościoła wykorzystania duchowych i duszpasterskich środków, by wzmocnić odwagę chrześcijan do dawania świadectwa. Temu celowi służyło m.in. sięganie do tysiącletniej historii chrześcijaństwa na polskich ziemiach oraz formowanie świadomości i postaw ludzi wierzących. W tej historycznej perspektywie nawiązanie do sakramentów chrztu i bierzmowania dawało możliwość nie tylko potwierdzenia chrześcijańskiej tożsamości narodu, lecz także stanowiło szansę, by pogłębić wiarę ludzi, ukazać moc łaski Chrystusa, którą sakramenty chrztu i bierzmowania wnoszą w życie chrześcijan. Ich świadectwo życia wzbogaca dzieje Ojczyzny.

Obchody Tysiąclecia Chrztu Polski w roku 1966, poprzedzone Wielką Nowenną (1957-1965), ukazały olbrzymie dzieło ewangelizacji, zapoczątkowanej głoszeniem Ewangelii na ziemiach polskich przez pierwszych misjonarzy. Misja ta była

${ }^{49}$ Po wyborze na następcę św. Piotra Jan Paweł II dokonał uroczystego zamknięcia Synodu 8 czerwca 1979 roku. Por. Pielgrzymka Jana Pawła II do Polski: przemówienia, dokumentacja. Tekst autoryzowany, dz. cyt., s. 172-174.

${ }^{50}$ Por. Duszpasterski Synod Archidiecezji Krakowskiej 1972-1979, t. 1: Przebieg prac synodalnych. Dokumenty Synodu, Kraków 1985, s. 281-283. Cały dokument, tamże, s. 267-285.

${ }^{51}$ Por. Sobór Watykański II, Dekret o apostolstwie świeckich Apostolicam actuositatem, 3. 
kontynuowana także po przyjęciu przez księcia Mieszka I chrztu w 966 roku. Szczególne znaczenie posiadała misja św. Wojciecha, który przypieczętował dzieło ewangelizacji własnym męczeństwem. Jej owocem był ustanowienie w roku 1000 organizacji hierarchicznej na ziemiach polskich: metropolii gnieźnieńskiej oraz diecezji w Krakowie, Kołobrzegu i Wrocławiu. Obchody milenijne podkreślały znaczenie dziedzictwa chrześcijańskiej wiary i rolę Kościoła, w którym społeczność Polaków, w większości katolicka, znajdowała oparcie w trudnych czasach: podczas rozbiorów, okupacji niemieckiej czy w okresie komunizmu, oraz pomoc w utrzymaniu i pogłębieniu tożsamości narodu, tożsamości polskiej złączonej ściśle z chrześcijaństwem ${ }^{52}$. Teologia dziejów, zawarta w programie duszpasterskim Wielkiej Nowenny i Millennium, ukazywała Ducha Świętego, który działa w historii, otwiera serca ludzkie na Chrystusa i w ten sposób przemienia oblicze ziemi. Jak naród polski został włączony we wspólnotę narodów chrześcijańskich, tak i każdy chrześcijanin włączony jest przez chrzest we wspólnotę Kościoła. Otrzymuje „klucz” do dogłębnego zrozumienia siebie, sensu swojego życia i przemijania.

Warto w tym miejscu przywołać słowa Jan Pawła II wypowiedziane w Warszawie w 1979 roku odnoszące się do chrześcijańskiego dziedzictwa zapoczątkowanego misją św. Wojciecha:

Kościół przyniósł Polsce Chrystusa - to znaczy klucz do rozumienia tej wielkiej i podstawowej rzeczywistości, jaką jest człowiek. Człowieka bowiem nie można do końca zrozumieć bez Chrystusa. [...]. I dlatego Chrystusa nie można wyłączyć z dziejów człowieka w jakimkolwiek miejscu ziemi. Nie można też bez Chrystusa zrozumieć dziejów Polski [...]. A dzieje każdego człowieka toczą się w Jezusie Chrystusie. W Nim stają się dziejami zbawienia ${ }^{53}$.

W tych słowach Papież podkreślił centralne znaczenie osoby Chrystusa w chrześcijańskiej wierze, ale również Jego znaczenie dla koncepcji człowieka, życia ludzkiego i historii.

Należy przypomnieć, że ostatnie lata Wielkiej Nowenny zbiegły się w czasie z trwaniem Soboru Watykańskiego II (1962-1965). Po obchodach milenijnych w 1966 roku rozpoczął się w Kościele polskim proces wcielania w życie postanowień soborowych. Według kard. Wojtyły realizacja Vaticanum II miała na celu pogłębienie świadomości wiary i kształtowanie chrześcijańskich postaw w codziennym życiu, czyli ukazanie tego, co oznacza być człowiekiem wierzącym

52 Por. Jan Paweł II, Przemówienie do plenarnej Konferencji Episkopatu Polski, Jasna Góra, 5.06.1979, [w:] Pielgrzymka Jana Pawła II do Polski: przemówienia, dokumentacja. Tekst autoryzowany, dz. cyt., s. 87-89.

${ }^{53}$ Jan Paweł II, Homilia na Placu Zwycięstwa, Warszawa, 2.06.1979, [w:] tamże, s. 22. 
dzisiaj, biorąc odpowiedzialność za zbawienie własne i innych oraz za kondycję moralną współczesnego świata ${ }^{54}$. Metropolita krakowski związał realizację dzieła Soboru Watykańskiego II z Synodem Duszpasterskim Archidiecezji Krakowskiej oraz z przygotowaniem do uroczystości 900-lecia męczeństwa św. Stanisława.

Karol Wojtyła dostrzegał związek pomiędzy Tysiącleciem Chrztu Polski a Soborem Watykańskim II, wskazując, że zrozumienie znaczenia przeszłości stanowi pomoc w wytyczeniu właściwych dróg na przyszłość. W tym też celu zwrócił uwagę na dwóch głównych patronów Polski: św. Wojciecha i św. Stanisława. Postać pierwszego wiąże się z chrztem Polski, przekazaniem dziedzictwa wiary, włączeniem w Chrystusa i Kościół, które powoduje sakrament chrztu. Natomiast postać św. Stanisława i jego misję można w sposób symboliczny złączyć z sakramentem bierzmowania. „Zmysł chrześcijański Ludu Bożego żyjącego na ziemi polskiej - pisał Wojtyła - widzi w jego postaci jakby historyczne świadectwo dojrzałości, które dla rozwoju wiary jednostek i społeczeństw niesie właśnie sakrament bierzmowania" ${ }^{\text {. }}$. Życie św. Stanisława wskazuje na dojrzałe owoce wiary, dlatego ten święty nazywany jest patronem ładu moralnego. Dojrzała wiara wiąże się z doskonaleniem moralnym chrześcijanina, a także ze wzrostem odpowiedzialności moralnej społeczeństwa. Kardynał Wojtyła podkreślił, że św. Stanisław jest niejako wyzwaniem, by poznawać, umacniać i pogłębiać wiarę oraz dawać odważne świadectwo przynależności do Chrystusa. W przemówieniu podczas otwarcia synodu kardynał podkreślił:

Tak bowiem jak św. Stanisław, na miarę swoich czasów, starał się doprowadzić wiarę naszych przodków do własnej dojrzałości, tak i nam Sobór Watykański II dał wskazania, rzucił wezwanie, ażebyśmy wiarę naszą doprowadzili do takiej dojrzałości, jakiej domaga się miara naszych czasów ${ }^{56}$.

Ważne jest, by zauważyć, że postać św. Stanisława nie jest tylko wzorem czy inspiracją, lecz stanowi przejaw ,żywej tradycji”, która także kształtuje świadomość i moralne wybory ludzi.

Znamienny pozostaje fakt, że pierwsza pielgrzymka Jana Pawła II do Ojczyzny w 1979 roku wiązała się z obchodami 900-lecia męczeństwa św. Stanisława. Trzeba także przypomnieć, że pielgrzymka rozpoczęła się w wigilię uroczystości Zesłania

${ }^{54}$ Por. K. Wojtyła, U podstaw odnowy. Studium o realizacji Vaticanum II, wyd. 3, Kraków 2003, s. 11 i 296-297.

${ }^{55}$ K. Wojtyła, List pasterski w związku z 900 rocznicą św. Stanisława, 25.03. 1972, [w:] Duszpasterski Synod Archidiecezji Krakowskiej 1972-1979, t. 2: Dokumentacja, Kraków 1985, s. 35.

${ }^{56}$ K. Wojtyła, Przemówienie w czasie otwarcia Duszpasterskiego Synodu Archidiecezji Krakowskiej, [w:] tamże, s. 57-58. 
Ducha Świętego, 2 czerwca 1979 roku. Ojciec Święty podkreślił, że dzięki działaniu Ducha Świętego dzieje każdego człowieka i dzieje Polski wpisują się w nurt wielkiej historii zbawienia. Pielgrzymka ta rozpoczęła się na Placu Zwycięstwa w Warszawie od wezwania Ducha Świętego: „Wołam, ja, syn polskiej ziemi, a zarazem ja: Jan Paweł II, papież, wołam z całej głębi tego Tysiąclecia, [...]. Niech zstąpi Duch Twój! I odnowi oblicze ziemi. Tej ziemi”"57.

Pielgrzymka zakończyła się mszą świętą ku czci św. Stanisława na krakowskich Błoniach, 10 czerwca 1979 roku. Papież nadał tej uroczystości charakter symbolicznego „bierzmowania dziejów”, umocnienia Duchem Świętym polskiego narodu. Przypomniał w homilii, że bierzmowanie ,jest sakramentem, który powinien rodzić w nas szczególne poczucie odpowiedzialności za Kościół, za Ewangelię, za sprawę Chrystusa w duszach ludzkich, za zbawienie świata" ${ }^{8}$. Podkreślił, że na obecnym etapie dziejów jego rodacy bardzo potrzebują dojrzałej wiary złączonej ze świadectwem życia, by zwycięsko przejść przez „wielką próbę wiary i charakterów", której zostali poddani. W dużej mierze próba ta wynikała z braku wolności i z narzuconej Polakom ideologii materialistycznej i ustroju komunistycznego. Od każdego zwycięstwa moralnego - tłumaczył Papież - od każdego świadectwa wiary jednostek i wspólnot zależy zwycięstwo ładu moralnego w narodzie, utwierdzenie jego tożsamości i podmiotowości. Święty Stanisław jest patronem tego procesu formowania dojrzałej postawy wiary, który polega na realizacji nauki Soboru Watykańskiego $\mathrm{II}^{59}$.

Po nakreśleniu tej historycznej i teologicznej perspektywy Jan Paweł II dokonał pewnego rodzaju duchowego odnowienia łaski sakramentu bierzmowania, zbiorowego odnowienia świadomości mocy, którą ten sakrament zawiera, i zadań, do których zobowiązuje. „Pozwólcie przeto - mówił - że tak jak zawsze przy bierzmowaniu biskup, i ja dzisiaj dokonam owego apostolskiego włożenia rąk na wszystkich zgromadzonych, na wszystkich moich rodaków. W tym włożeniu rąk wyraża się przejęcie i przekazanie Ducha Świętego, którego Apostołowie otrzymali od samego Chrystusa, kiedy po Zmartwychwstaniu przyszedł do nich «drzwiami zamkniętymi» (por. J 20, 19) i rzekł:

${ }^{57}$ Jan Paweł II, Homilia wygłoszona na placu Zwycięstwa, dz. cyt., s. 24. W homilii wygłoszonej w Gnieźnie podkreślił, że trzeba wsłuchać się w „mowę Ducha Świętego” na obecnym etapie dziejów, by z nadzieją móc podążać ku przyszłości. Por. tenże, Homilia wygłoszona podczas Mszy św., Gniezno, 3.06.1979, [w:] Pielgrzymka Jana Pawła II do Polski: przemówienia, dokumentacja. Tekst autoryzowany, dz. cyt., s. 34-40.

${ }^{58}$ Tenże, Homilia podczas uroczystej Mszy św. ku czci świętego Stanisława, Kraków, 10.06.1979, [w:] Pielgrzymka Jana Pawta II do Polski: przemówienia, dokumentacja. Tekst autoryzowany, dz. cyt., s. 207-208.

${ }^{59}$ Por. tamże. 
«Weźmijcie Ducha Świętego» (J 20, 22). Tego Ducha: Ducha zbawienia, odkupienia, nawrócenia i świętości, Ducha prawdy, Ducha miłości i Ducha męstwa - odziedziczonego jako żywą Moc po Apostołach - przekazywały po tyle razy biskupie dłonie całym pokoleniom na ziemi polskiej. [...] Pragnę wam dziś przekazać tego Ducha, ogarniając sercem z najgłębszą pokorą to wielkie bierzmowanie dziejów, które przeżywacie. [...] Musicie być mocni, drodzy bracia i siostry, mocą tej wiary, nadziei i miłości świadomej, dojrzałej, odpowiedzialnej, która pomaga nam podejmować ów wielki dialog z człowiekiem i światem na naszym etapie dziejów $[\ldots]^{60}$.

Trzeba zauważyć, że pierwsza pielgrzymka Jana Pawła II wiązała się z przypomnieniem roli Ducha Świętego w naszej wierze, była swoistą ,anamnezą”, ale także stanowiła gorącą modlitwę o otwarcie ludzkich serc na Jego działanie oraz była wołaniem - „epiklezą”, by Duch przyszedł i umocnił wierzących swoimi darami. Duch Święty, którego przyjmujemy w sposób szczególny w sakramencie bierzmowania, przynosi łaskę do mężnego wyznawania Chrystusowej wiary, do wierności chrześcijańskiemu dziedzictwu, do Bożej nadziei przynoszącej radość z życia, także wtedy, kiedy wiąże się ono z trudnościami i cierpieniem, do ewangelicznej miłości, dojrzałej i pełnej poświęcenia. „Gdy jesteśmy mocni Duchem Boga, jesteśmy także mocni wiarą w człowieka - wiarą, nadzieją i miłością: są one nierozerwalne i jesteśmy gotowi świadczyć sprawie człowieka wobec każdego, któremu ta sprawa prawdziwie leży na sercu"61. Uwierzyć w Ducha Świętego znaczy pozwolić mu działać i stać się zarazem narzędziem Jego działania w świecie.

Do tej prawdy wrócił Jan Paweł II podczas Światowego Dnia Młodzieży na Jasnej Górze, 15 sierpnia 1991 roku. Fakt, że po przemianach politycznych w Europie, w spotkaniu mogli wziąć udział młodzi ludzie z Zachodu i Wschodu, Ojciec Święty uznał za wielki dar Ducha Świętego. „Kościół w Europie może w końcu oddychać swobodnie obydwoma swoimi płucami” ${ }^{62}$ - powiedział. Po upadku murów ideologicznych dzielących ludzi potrzebna jest dalsza współpraca z Duchem Świętym.

Pozwólcie - mówił Papież do młodych - by Duch mądrości i rozumu, Duch rady i męstwa, Duch wiedzy, pobożności i bojaźni Pańskiej przenikał wasze serca i wasze życie i by za waszym pośrednictwem przekształcał oblicze ziemi ${ }^{63}$.

${ }^{60}$ Tamże, s. 207 i 209.

${ }^{61}$ Tamże, s. 210-211.

${ }^{62}$ Jan Paweł II, Otrzymaliście Ducha przybrania za synów, 15.08.1991, [w:] Jan Paweł II: VI Międzynarodowy Dzień Młodzieży w Częstochowie. Drugi etap czwartej pielgrzymki duszpasterskiej do Polski, 13-16 sierpnia 1991, Città del Vaticano 1992, s. 60.

${ }^{63}$ Tamże. 
W trakcie głównej mszy świętej, Jan Paweł II nawiązał w homilii do sakramentu bierzmowania, podobnie jak uczynił to na krakowskich Błoniach: „Podobnie jak w dniu bierzmowania mówił do was biskup, i ja powtarzam wam, młodym, którzy przybyliście tu ze wszystkich kontynentów: Przyjmijcie Ducha Świętego! Przeniknięci mocą, która od Niego pochodzi, stawajcie się budowniczymi nowego świata: świata innego, opartego na prawdzie, na sprawiedliwości, na solidarności, na miłości”. Zakończył homilię słowami: „Oto nowe Zielone Święta, nowa Pięćdziesiątnica: Kościół jeszcze raz zgromadzony razem z Maryją, Kościół młody, Kościół misyjny, świadom swojego posłannictwa. Drodzy młodzi przyjaciele! Przyjmijcie Ducha Świętego i bądźcie mocni!"”4.

Nawiązując do sakramentu bierzmowania w istotnych momentach dziejów Kościoła współczesnego, jakimi były pierwsza wizyta papieska w Polsce czy Światowy Dzień Młodzieży w Częstochowie, Jan Paweł II przypominał o społecznym wymiarze życia sakramentalnego. Jak przez chrzest tworzy się wspólnota ochrzczonych, Kościół, tak przez bierzmowanie tworzy się wspólnota świadków Chrystusa, która jest zaczynem nowego świata.

Od wczesnych lat młodości Karol Wojtyła pozwalał się prowadzić Duchowi Świętemu, który wytyczył drogę jego życia i przygotował na podejmowanie wyzwań życiowych i duszpasterskich z miłością do Boga i ludzi. Doświadczając osobiście darów i owoców działania Pocieszyciela, rozumiał, jak ważne jest otwieranie serc ludzkich na Jego obecność i Jego światło ukazujące prawdę Ewangelii. Duch Święty daje moc świadczenia o Chrystusie i siłę do apostolstwa. Sakrament bierzmowania stanowił w posłudze biskupiej Wojtyły odpowiednią okazję, by uwrażliwić młodzież na działanie Ducha Świętego. Otwarcie na Ducha i stała współpraca z Nim sprawiają, że chrześcijanin staje się apostołem i promieniuje świętością. Teologiczne inspiracje dla „bierzmowania dziejów”, które dokonało się na krakowskich Błoniach w roku 1979, można znaleźć nie tylko w teologii będącej u podłoża Wielkiej Nowenny i Millennium oraz w teologiczno-symbolicznej wymowie 900-lecia męczeństwa św. Stanisława. Uwidaczniają się one także w osobistej wrażliwości Karola Wojtyły - Jana Pawła II na działanie Ducha w sakramencie bierzmowania i w jego przekonaniu o konieczności podkreślania apostolskiego oraz społecznego wymiaru tego sakramentu.

${ }^{64}$ Tamże, s. 60 i 63. 
Osoby szczególnie wrażliwe na działanie Ducha Świętego lepiej dostrzegają pragnienie Ducha, ukryte często pod pokładami doczesnych dążeń ludzi oraz ich tęsknoty za światem bardziej ludzkim, za sprawiedliwością, wzajemnym szacunkiem i pokojem. Na progu pontyfikatu, w encyklice Redemptor hominis, której treść - jak wyznał - „przywiózł z sobą z Polski”" ${ }^{65}$, Jan Paweł II podkreślił, że nasza epoka jest szczególnie „głodna Ducha”. Chrześcijanie przyzywają Ducha Świętego, by wejść w pełny wymiar tajemnicy odkupienia, by żyć godnością synów Bożych i by z Chrystusem Panem iść na spotkanie Ojca w wieczności. Dzięki świadectwu wiary wyznawców Chrystusa to „wołanie o Ducha Świętego” staje się także odpowiedzią na wszystkie materializmy naszej epoki, na fałszywe ideologie, na brak sprawiedliwości, pokoju, dobroci, męstwa, odpowiedzialności, szacunku dla godności ludzkiej ${ }^{66}$. Bez tego usilnego wołania o Ducha nie można więc sobie wyobrazić kontynuowania i rozwoju misji Kościoła we współczesnym świecie; misji, która polega na zbawieniu człowieka i która także ma na celu ukazanie piękna i prawdy człowieczeństwa. „Kościół - jak podkreślił Jan Paweł II w Redemptor hominis - starając się patrzeć na człowieka niejako «oczyma samego Chrystusa», uświadamia sobie wciąż na nowo, iż jest stróżem wielkiego skarbu, którego nie wolno mu rozproszyć, który wciąż musi pomnażać" ${ }^{67}$. Dlatego Kościół naszej epoki „z jeszcze większą zda się żarliwością, ze świętą natarczywością, powtarza Veni, Sancte Spiritus! Przyjdź! Przybądź!’68.

W tym wołaniu o Ducha Świętego słychać pragnienie realizacji duchowego potencjału, jaki powinno wnosić bierzmowanie, zarówno w życie indywidualne, jak i społeczne. Działanie Pocieszyciela w życiu indywidualnych chrześcijan i w życiu Kościoła, czasem w sposób nie do przewidzenia, a nawet i precyzyjnego rozpoznania, przenosi się na życie społeczne i polityczne. W ten sposób też kształtują się pod wpływem Ducha dzieje narodów i historia ludzkości. Warunkiem tego procesu jest jednak to, by w ludziach wierzących, umocnionych bierzmowaniem, „przejawiały się moce Ducha, dary Ducha, owoce Ducha Świętego"69.

Dlatego tak wielkiego uznania i wsparcia potrzebuje praca duszpasterska mająca na celu przygotowanie młodzieży do tego sakramentu w dzisiejszych czasach, w których tak wiele głosów chce zagłuszyć czy zlekceważyć to ukryte w człowieku wołanie o Ducha. Młodzi są nadzieją Kościoła, ale ta nadzieja wykuwa się w mozolnej pracy nad umysłami, sercami i sumieniami młodych ludzi. Trzeba też często w pracy duszpasterskiej powracać do bierzmowania i uświadamiać

\footnotetext{
${ }^{65}$ Jan Paweł II, Pamięć i tożsamość. Rozmowy na przełomie tysiącleci, Kraków 2005, s. 13.

${ }^{66}$ Por. tenże, Encyklika u początku papieskiej posługi Redemptor hominis, 18.

${ }^{67}$ Tamże.

${ }^{68}$ Tamże.

${ }^{69}$ Tamże.
} 
dorosłym wielki dar, który przyjęli i może zaniedbali. Zmaganie się o „narodziny wyznawców", o gorliwość apostolską, która nie jest tylko aktywnością religijną, lecz przejawem mocy Ducha Świętego, to w istocie zmaganie o świętość, o świadków miłości Boga i człowieka. „W rzeczywistości świętość jest darem i zadaniem - stwierdził Jan Paweł II - zakorzenionym w chrzcie i bierzmowaniu, powierzonym wszystkim członkom Kościoła w każdej epoce. Jest darem i zadaniem dla świeckich tak samo jak dla zakonników i kapłanów, w sferze prywatnej tak jak w działalności publicznej, w życiu zarówno jednostek, jak rodzin i wspólnot"70.

Życie Jana Pawła II było potwierdzeniem tego, że świętość rodzi się ze współpracy z Duchem Świętym, z ufnego powierzenia się miłosierdziu Ojca i z bliskiej relacji z Chrystusem, z osobistego zaangażowania w sprawę ewangelizacji. Świadectwo jego życia ukazuje dobitnie, że ci, których ,prowadzi Duch Boży, są synami Bożymi” i „współdziedzicami Chrystusa”, a nasze doczesne zmagania, nawet cierpienia, są po to, by mieć udział w chwale nieba. Życie Jana Pawła II przypomina również, że „całe stworzenie z upragnieniem oczekuje na objawienie się synów Bożych”. Duch Święty przyczynia się zaś nieustannie za tymi, którzy dążą do świętości (por. Rz 8, 14-19. 27).

\section{Abstrakt \\ Od bierzmowania w życiu i posłudze pasterskiej Karola Wojtyły do „bierzmowania dziejów” Jana Pawła II}

Artykuł ukazuje działanie Ducha Świętego w życiu chrześcijan i w apostolskiej misji Kościoła. Przypomina o roli modlitwy do Ducha Świętego w życiu Karola Wojtyły oraz jego zaangażowanie duszpasterskie związane z udzielaniem sakramentu bierzmowania. Pełniąc posługę biskupa krakowskiego, kładł on nacisk na wyjaśnienie teologii bierzmowania i jego znaczenia w życiu chrześcijanina i wspólnoty Kościoła. Jako przewodniczący Komisji Apostolstwa Świeckich, działającej w ramach Konferencji Episkopatu Polski, zaproponował przeprowadzenie zmian w programie pastoralnym, mających na celu większe podkreślenie znaczenia bierzmowania dla apostolstwa młodych. Podczas papieskich wizyt w Polsce w 1979 i 1991 roku Jan Paweł II dokonał odnowy sakramentu bierzmowania w wymiarze eklezjalnym, narodowym i historycznym, zwracając tym samym uwagę na działanie Ducha Świętego w sercach ludzi i w historii.

Słowa kluczowe: Karol Wojtyła, Jan Paweł II, Duch Święty, bierzmowanie

${ }^{70}$ Jan Paweł II, Orędzie na XIII Światowy Dzień Młodzieży, „L’Osservatore Romano”, wyd. pol., 1998 nr 2, s. 6 . 


\section{Abstract \\ From confirmation in Karol Wojtyla's life and ministry to the "great confirmation of history" completed by John Paul II}

The article shows the work of the Holy Spirit in the lives of Christians and in the apostolic mission of the Church. It underlines the role of prayer to the Holy Spirit in Karol Wojtyła's life as well as his apostolic commitment associated with receiving the sacrament of Confirmation. During his pastoral ministry as the Bishop of Krakow he gave special attention to explain the doctrine of this sacrament; putting out its significance for individuals and parish communities. Cardinal Wojtyła, as the head of Commission for the Lay Apostolate in the Polish Episcopate, proposed some specific reforms in the pastoral programs to increase the significance of Confirmation for the apostolic engagement of young people. He was convinced that different forms of renewal of Confirmation were needed in the pastoral life of the Church. During his visit in Poland in 1979 and 1991, John Paul II proposed a rite of renewal in the historical context, emphasizing the role of the Holy Spirit in contemporary history and the need to be open to his work in ours lives.

Keywords: Karol Wojtyła, John Paul II, the Holy Spirit, confirmation

\section{Bibliografia}

Bierzmowanie jako sakrament apostolstwa (cztery strony maszynopisu), Archiwum Kurii Metropolitalnej w Krakowie (AKKW F V - 4/137e).

Cazzago A., „Jeszcze dziś stysze jego głos”. Jan Paweł II mówi o swoim ojcu, „Communio” 30 (2010) nr 2, s. 79-87.

Dokumenty duszpastersko-liturgiczne Episkopatu Polski (1966-1998), oprac. C. Krakowiak, L. Adamowicz, Lublin 1999.

Duszpasterski Synod Archidiecezji Krakowskiej 1972-1979, t. 1: Przebieg prac synodalnych.

Dokumenty Synodu, t. 2: Dokumentacja, Kraków 1985.

Dyduch J., Kardynał Karol Wojtyła w stużbie Konferencji Episkopatu Polski, Kraków 2007.

Frossard A., Nie lękajcie się! Rozmowy z Janem Pawłem II, Città del Vaticano 1982.

Frossard A., Portret Jana Pawła II, Kraków 1990.

Jan Paweł II, Dar i Tajemnica. W pięćdziesiąta rocznicę moich święceń kapłańskich, Kraków 1996. Jan Paweł II, Przekroczyć próg nadziei, Lublin 1994.

Komisja Apostolstwa Świeckich, Bierzmowanie jako sakrament apostolstwa, „Notificationes e Curia Metropolitana Cracoviensi" 1975 nr 3-4, s. 35-38.

Komisja Apostolstwa Świeckich, Uwagi dotyczace bierzmowania jako sakramentu inicjującego świadoma postawe apostolska wiernych (cztery strony maszynopisu), Archiwum Kurii Metropolitalnej w Krakowie (AKKW F V - 7/33). 
Konferencja Episkopatu Polski, Instrukcja duszpasterska dotyczaca sakramentu bierzmowania, „Notificationes e Curia Metropolitana Cracoviensi” 1975 nr 3-4, s. 30-35.

Pięknie jest stużyć. Dziedzictwo duchowe Jana Pawła II, red. A. Dobrzyński, Rzym 2013.

Szafarski M., Perła ewangeliczna. Stuga Boży Jan Leopold Tyranowski 1901-1947, Wrocław 2000.

Weigel G., Świadek nadziei. Biografia papieża Jana Pawła II, Kraków 2000.

Wojtyła K. - Jan Paweł II, Narodziny wyznawców. Refleksje o bierzmowaniu, oprac. A. Dobrzyński, Rzym 2014.

Wojtyła K. - Jan Paweł II, Poezje, dramaty, szkice. Tryptyk rzymski, Kraków 2004.

Wojtyła K., Aby Chrystus się nami postugiwat, Kraków 1979.

Wojtyła K., U podstaw odnowy. Studium o realizacji Vaticanum II, Kraków 2003. 